\title{
Factors Affecting the Success of Government Audits: A Case Study of Pakistan
}

\author{
Anam Masood ${ }^{1, *}$, Rab Nawaz Lodhi ${ }^{2}$ \\ ${ }^{1}$ Department of Management sciences, Lahore College for Women University, Pakistan \\ ${ }^{2}$ Institute of Business Administration, University of Engineering and Technology, Pakistan
}

Copyright $@ 2015$ Horizon Research Publishing All rights reserved.

\begin{abstract}
This research is undertaken to explore the antecedents behind ineffective audits at government level. Government audits carry significant importance to make government entities accountable for utilization of funds for public welfare. In Pakistan, corruption and misappropriation of funds at government level is continuously destroying public trust and economic welfare. To rectify the situation, it is necessary to make audit effective. The data has been collected from fifteen government auditors of Pakistan through face to face in- depth interviews. The main themes in interviews were coded in QSR NVIVO 10 and presented through word tree maps, word tag cloud and Nvivo based conceptual model. Pearson correlation coefficients have been generated to determine the relationship between several antecedents and ineffective government audits. Pattern of talk concluded that massive corruption, conservative auditing methods, lack of cooperation from auditee, low morale of auditors, lack of financial independence, lack of power to take action against malpractices, lack of financial, technological and human resources, lack of qualified trainers and ineffective training institutes are antecedents of ineffective audits which ultimately make it difficult to bring transparency and accountability in the public sector. It is recommended that Parliament should facilitate government auditors through the availability of sufficient resources, training and growth opportunities.
\end{abstract}

Keywords Accountability, Government, Auditors, Transparency, QSR Nvivo 10, Audit

\section{Introduction and Literature}

In Pakistan, trust of the general public in government is weak because of different scandals of government entities highlighted by government auditors. According to corruption Index (CI) 2012 prepared by transparency International, CI scores of Pakistan 27, New Zealand 90, Canada 84, Australia 85, UK 74, China 39, India 36, Afghanistan 8, North Korea 8 which shows that scores nearer to 100 are less corrupt, comparatively Pakistan is one the most corrupt country because of lack of accountability and proactive supervision. So, this phenomenon leads our attention to the effectiveness of the audit. An audit is an independent examination of an entity by an auditor, who delivers reports about facts observed to the best of his knowledge. Audit is exercised to hold an organization accountable for their deeds. Audits are effective if they are strong enough to transparently highlight performance lags of government entities [1]. An audit can be made effective if problems and issues of auditors are resolved.

The government collects revenue from people in the form of taxes, and those taxes are planned and allocated in the form of budget in Parliament, who is representative of the public. Parliament allocates that budget to different ministries, e.g. education, food, law, tourism, shipping, power development, housing and commerce deliver services to the public at their best. These ministries work as the agent of parliament because they utilize public funds on behalf of Parliament. In order to ensure that they are working economically, effectively and efficiently, the Parliament appoints auditors as watch dogs to evaluate performance of those ministries and to make them accountable for the proper appropriation of public money. Government auditors have to bring accountability, transparency and good governance to manage public funds.

As per researcher's knowledge, no prior research is conducted to explore factors which affect government auditors to achieve their goal. Issues and problems faced by government auditors in Western and Asian countries serve as a basis for this study.

Effective audits are the outcome of auditor's efforts [2] which are directly affected by best human resources practices-training, career development, knowledge sharing and management, performance appraisals, promotion systems and job security- which have a positive impact on employee performance $[3,4,5,6,7]$. In addition to it, knowledge, skills and educational level are important to affect performance of auditors [8]. Training of auditors is another important factor. There is a positive relation between training and employee performance $[9,10]$. If auditors are 
trained to conduct audits with the help of new auditing methods, effectiveness of audit can be increased. Availability of human, physical, intellectual and financial resources to the auditors are another important issue $[11,12]$.

In the UK, it was found that political powers pressurized government auditors for distorting audit reports for their own benefits. In addition to it, lack of professional staff and resources hampered working of government auditors [13]. In the United States, the characteristics of the audited firm and proficiencies of auditors positively affected audit effectiveness [14].

In west Australia, monopoly of government auditors, conventional auditing methods, lack of technology to store and share information negatively affected end results of audits [15]. Political interferences to change audit reports and audits, behavior of auditee with auditor affected audit effectiveness [16]. Moreover, reports prepared by internal audit departments of entities can save time and cost of auditors, but their reports lack reliability [17]. So, the presence of internal audit departments in auditing bodies was not useful for auditors.

In Estonia, government auditors were deprived of human resources and sufficient time to complete audit. Top level management was not committed to support auditors [18]. Political interferences to change audit reports were high [18].

On Cayman Island, government auditors suffered from lack of human, financial, informational and communications resources. Massive delays in forwarding reports for consideration to parliament and partial independence of government auditors as key factors, not only faced by Cayman Island but other four countries St Lucia, Trinidad and Tobago, Jamaica and Montserrat [19].

In Israeli settings, promotional and career development opportunities, top management support for auditors, independence from political interferences increased auditor's capability to conduct effective audit [20].

Research works in Bangladesh revealed that audit category; traits of the auditee and auditor, planning on how much audit was following recommendations were key indicators of audit effectiveness [21]. There were communication gaps about the understanding of audit reports which affected end conclusions and decisions of government expenditures for public [22]. The extent of the auditor's duties, operational independence, funds handling capacity, degree of national accountability and up to date auditing standards were determinants of effective public audits in Indonesia [23].

In Turkey, autonomy of government auditors, capacity for further investigations on suspected cases and competency to take actions against malpractices were key performance indicators of audit quality [24].

In Ghana, independence of government auditors, resource availability, auditee's cooperation, relations and involvement with stakeholders, audit evaluation criteria and conformance to auditing standards were determinants of audit effectiveness [25].

In the Gauteng province of South Africa, autonomy of government auditors, timely submission of audit reports to government, follow up of recommendations, cooperation of audit parties, effective audit opinion, innovative auditing methods and competent audit staff were the key success factors of public audit quality [26]. In Latin America, massive importance was placed on the relationship between civil participation and effectiveness of government audits [27]. General public must participate in whistle blowing activities to detect frauds.

In Auckland, government auditors did not enjoy operational independence. Media was not free to expose government corruption scandals as per reports issued by PASAI [28].

In European countries, government auditors were facing problems, e.g., insecure tenure, ill-advised government and lack of performance management system which hindered their effectiveness [29]. Research on European Union countries concluded that submission of reports to government, sharing of reports with public on websites and existence of internal audit department are determinants of effectiveness in Croatia [30]. Government auditors in Greece, Ireland, Netherlands, Slovakia and the Czech Republic, Poland, Ireland and Hungary did not have full financial independence, whereas these European Union countries have operational independence [30]. Audit quality, management support and auditee characteristics were determinants of audit effectiveness in Ethiopia [31].

The research work of UK, west Australia, Estonia, Ghana, Bangladesh, Auckland and Turkey was qualitative in nature. Data was collected through interviews. Their work provided a variety of issues which played influential role in making the audit in those countries ineffective.

This research is organized in seven components. After an introduction, research objectives, methodology, data analysis, conclusion, discussion along with recommendations and the implication has been presented.

\section{Research Objectives}

- To highlight factors which disturb the effective working of government auditors?

- To evaluate either those factors are different from other western and Asian research findings.

- To suggest remedial measures to improve audit effectiveness.

\section{Research Methodology}

\subsection{Nature and Sample of Study}

The qualitative research approach has been used to satisfy the research objectives. The purpose of this study is exploratory. The exploratory case study method has been used to explore the factors which make audits ineffective.

The data has been collected from fifteen senior 
government auditors, who have audited different government departments of Pakistan. It is a cross sectional study.

\subsection{Research Instrument}

Literature review suggested a variety of questions to be asked in interviews. Annexure shows interview guide which consists of twenty questions. In depth face to face interviews were conducted with government auditors at their workplace.

\subsection{Data Analysis Method}

For qualitative analysis of interviews, different techniques of NVIVO 10 have been used. It transcribes video, audio, pictures, PDF files and documented interviews to explore different themes (Lodhi \& Malik, 2013). Firstly, interviews were documented and then transcribed in NVIVO. Analysis of interviews has been presented through word tag cloud, word tree maps, model and cluster analysis of node similarity and Pearson correlation coefficients of variables.

\subsubsection{Word Tag Cloud}

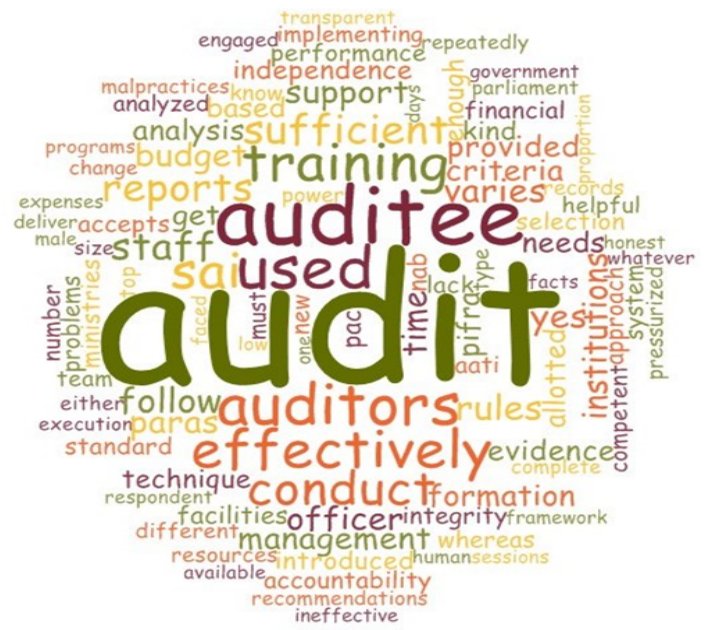

Figure 1. Word tag cloud
Word tag cloud (figure 1) helps to identify themes based on repetition of words. Size of frequently occurring words is greater than remaining words, which are showing different themes associated with effectiveness of government audits. For example, Budget, Financials, integrity, facilities, criteria, audit, audit, auditors, support, training, evidence, management, independence, time pressures and ineffectiveness are frequently occurring words. Word tag cloud does not show the direction of the relationship.

\subsubsection{Word Tree Map of Reference:}

Word tree map of reference nodes (Figure 2) shows the extent of responses for one variable. The greater the box size, the higher the number of references for that particular variable. Massive corruption has highest number of references, which shows that massive corruption is a significant cause of the ineffectiveness of government audits.

The word tree map has different sections with its associated nodes. Resource constraints, lack of financial resources, limited time available for audit, restricted access to auditee records are more critical antecedents than lack of human resources, lack of staff competency and lack of technology. In next section training of auditors, ineffective training institutes, use of new audit approaches has a much more significant impact on the effectiveness of government audits than need for learning materials, weak applicability of new audit approaches and lack of qualified trainers.

Section related with auditing techniques shows that lack of computerized auditing techniques and use of manual voucher based system has a much more significant impact on the effectiveness of auditors whereas auditors are not aware of System based approach of audit. In other sections, lack of powers to take actions against malpractices, high recommendatory powers, operational independence and financial dependence upon government have lower significance than auditor's follow up of audit, demotivated auditors and varying audit criteria.

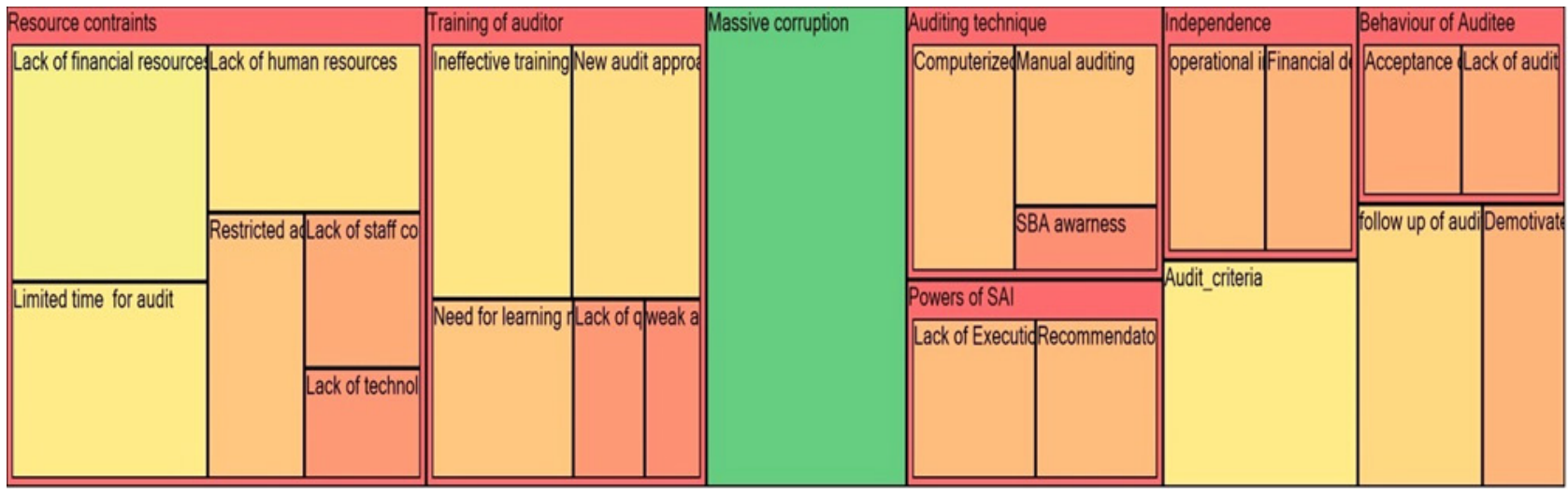

Figure 2. Word tree map of w.r.t number of references coded 


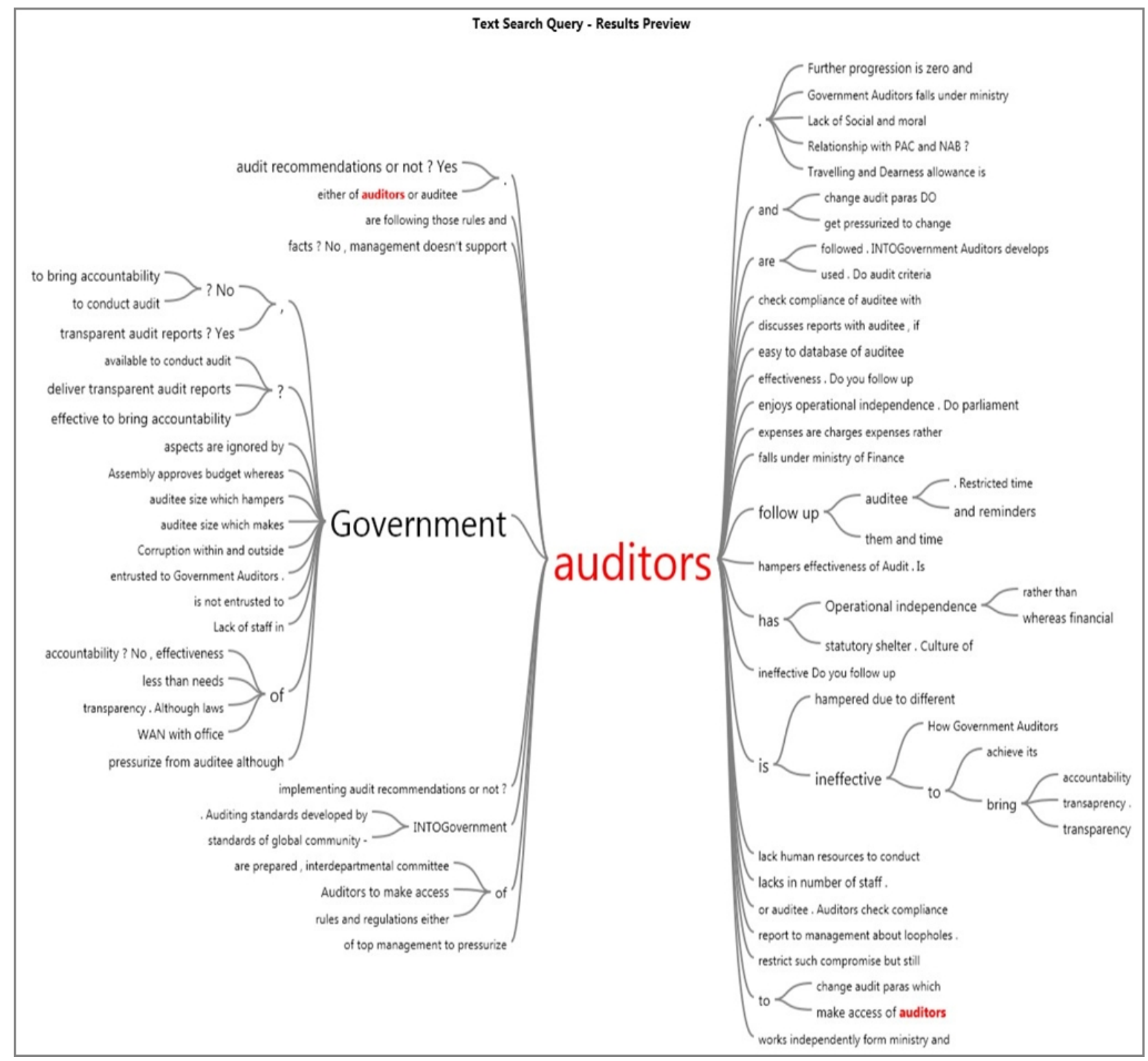

Figure 3. Word tree map

\subsubsection{Word Tree Map}

Word tree map (Figure 3) shows linkage of a central word with pattern of talk by respondents. The text search query shows different patterns which help to explore new themes in relation with other themes. Here, Auditors is a central word and responses associated with it are mapped to the left and right side.

It shows lack of staff, manipulation of audit reports, management support, pressures from top management to change audit reports and unawareness with new techniques, auditee size, pressures from auditee and restricted time available for audit are some patterns found to hamper the effectiveness of auditors to bring accountability and transparency.

\subsubsection{Nvivo based Model of study:}

Model (Figure 4) shows antecedents, which change the effectiveness of government audits to achieve its goals. Parent nodes are shown through rectangular shapes, and circles are showing child nodes. Backward nodes from child node to parent node show relationships between them and forward arrows from child nodes to the rounded rectangle show that government audits are affected through these factors. Model elaborates both dependent and independent variables. Government audits are used as dependent variables and remaining are independent variables. Training of auditors, resource constraints, behavior of audit, massive corruption, auditing techniques, powers of auditors, demotivation, follow up of audit recommendations, extent of auditing techniques, these are all independent variables which affect government auditors. 


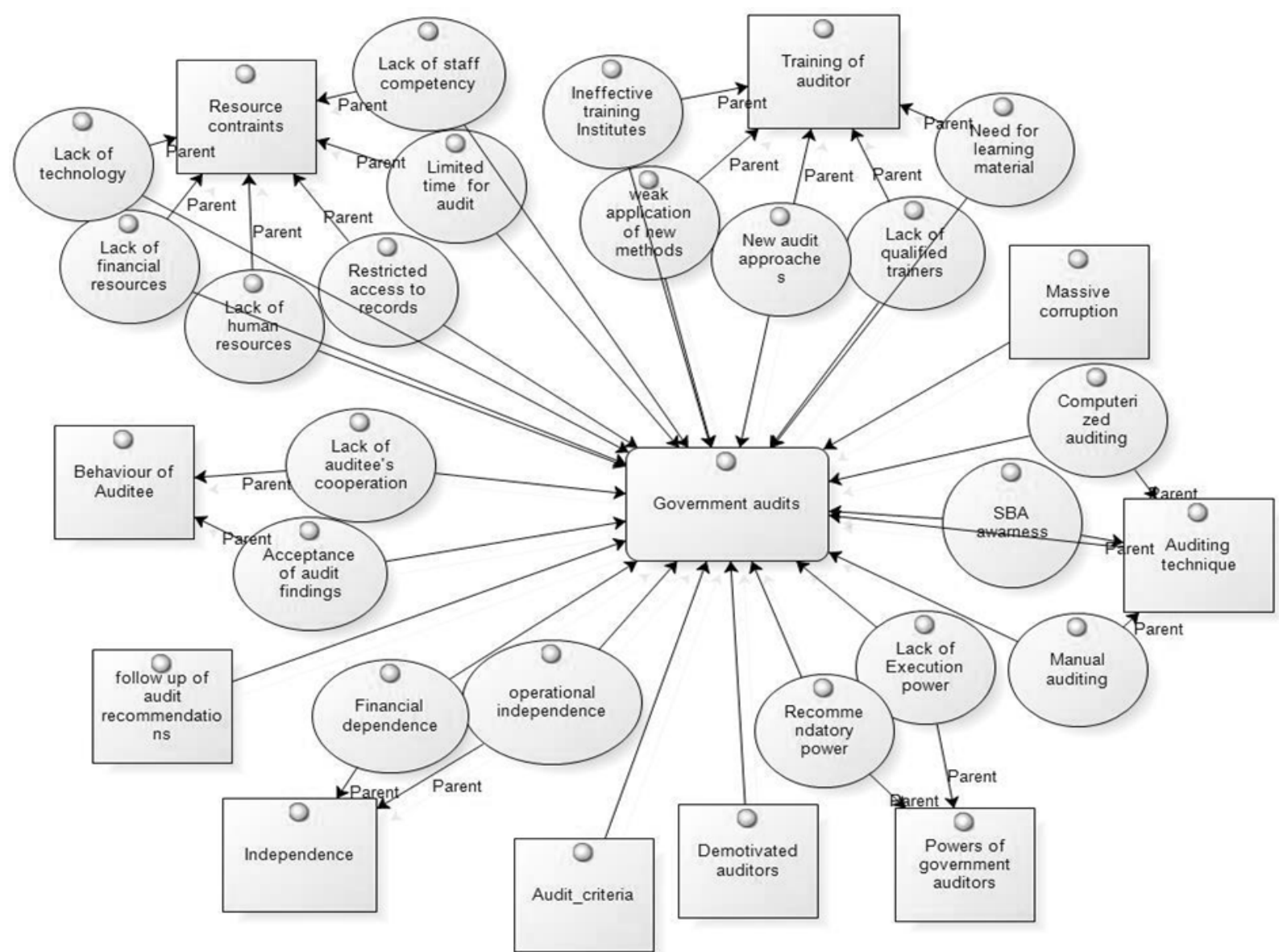

Figure 4. Conceptual model

Table 1. Pearson correlation coefficients between ineffective government audits and other variables

Node \Ineffective Government audits \Lack of financial resources

Node \\neffective Government audits $\backslash$ Limited time available for audit

Node \Ineffective Government audits $\backslash$ Lack of human resources

Node $\backslash$ Ineffective Government audits $\backslash$ Lack of technological resources

\section{Training of auditors}

Node $\backslash$ Government audits Ineffective training institutes

Node $\backslash$ Ineffective Government audits\New audit approaches $\quad-0.42$

Node $\backslash$ Ineffective Government audits\Need for learning material $\quad-0.32$

Nodel\Ineffective Government audits \Lack of qualified trainers $\quad 0.56$

Node \Ineffective Government audits $\backslash$ Weak applicability of new auditing methods $\quad 0.22$

$\begin{array}{ll}\text { Node } \backslash \text { Ineffective Government audits } \backslash \text { Massive corruption } & 0.99\end{array}$

$$
\text { Auditing techniques }
$$

Nodel\Ineffective Government audits $\backslash$ Computerized auditing methods $\quad-0.33$

$\begin{array}{lr}\text { Node } \backslash \text { Ineffective Government audits\Manual auditing } & 0.45\end{array}$

Powers of government auditors

Node $\backslash$ Ineffective Government audits $\backslash$ Lack of power to recommend $\quad 0.72$

Nodel\Ineffective Government audits\Lack of power to take actions $\quad 0.73$ Independence

Node $\backslash$ Ineffective Government audits $\lfloor$ Lack of financial independence $\quad 0.67$

Node $\backslash$ Ineffective Government audits\Operational independence $\quad-0.67$

Node\\Ineffective Government audits $\backslash$ Variation of Audit criteria $\quad 0.35$

Behavior of auditee

Node\\Ineffective Government audits \Lack of auditee's cooperation $\quad 0.77$

Node\\Ineffective Government audits\Lack of acceptance of audit findings by auditee 0.76

Nodel\Ineffective Government audits|Follow up by auditors $\quad-0.78$

Node $\backslash$ Ineffective Government audits $\backslash$ Demotivated auditors $\quad 0.81$ 


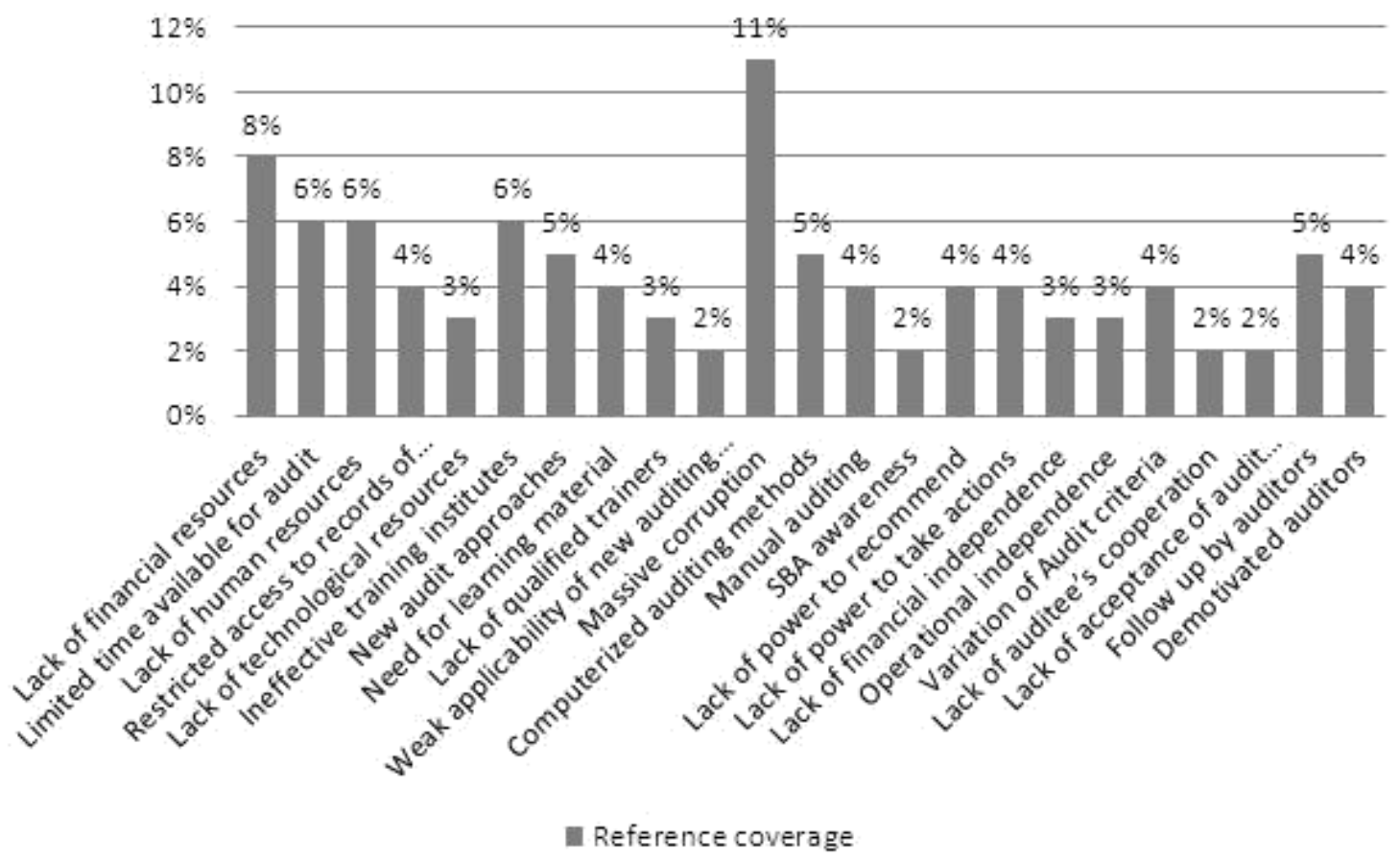

Figure 5. Percentage of reference coverage of each variable

\subsubsection{Quantitative analysis of relationships:}

Nvivo 10 generates the similarity metrics which show the relationship between two variables through the Pearson correlation coefficient ( -1 to 1$)$. If the Pearson correlation coefficient between two variables is nearer to one, it shows strong correlation between two variables. Table 1 shows the Pearson correlation coefficient between government audits and other variables. Most of the variables are positively related with ineffective government audits. Lack of financial resources, limited time available for the audit, lack of human resources, restricted access to the records of auditee, lack of technological resources, ineffective training institutes, lack of qualified trainers, massive corruption, use of manual auditing techniques, lack of power to recommend auditee and take actions against malpractices, lack of financial independence, demotivated auditors are positively related with ineffective government audits. Some variables have negative relationship with ineffective government audits. Use of new audit approaches, availability of learning material, the use of computerized auditing methods, full operational independence and strong follow up of auditee by auditors can minimize ineffectiveness of government audits. Among these variables, the correlation coefficient of massive corruption is most nearer to 1 , which indicates that massive corruption is a big issue behind ineffective audits. After that, lack of financial resources, limited time available for audit and low morale of government auditors is strong antecedents behind ineffectiveness of government audits.

\section{Results}

Nvivo based output presented different factors which are discussed here with statements of interviewers to make analysis more strong. Moreover, reference coverage chart (Figure 5) has been displayed at the end of results to show how much reference each variable carries from the data of interviews.

\subsection{Resource Constraints:}

Resources are the backbone of any organization. Resources can be categorized in terms of financial resources, human resources and technological resources. Auditors respond that appropriate budget is not allocated for an audit, so they are unable to have laptops and internet facilities. Auditors are not paid allowances in time. Time allotted to conduct audit has been always short enough that they are unable to complete audit of an entity. Auditors said that,

"Human resources, financial and non-financial resources, volume of work in proportion to man days, transport, Internet and laptop facilities need considerable attention..... Logistics and office stationery, laptops, internet access, supportive environment, conveyance, travelling and dearness allowance must be provided to conduct audit effectively."

"Budget is less than our needs. Travelling and Dearness allowance is not given this year. The government has imposed $30 \%$ cuts in budget for saving purpose. Such budget is not sufficient to conduct audits for a whole year. In six months budget expires."

Another important issue was related to time period available to complete the audit. Limited time is available, hardly four to five days to complete audit.

Irrespective of size of auditee organization which 
ultimately hampers appropriate presentation of auditee's performance. One of the auditors said that,

"Time is not allotted according to size. Proper time must be allotted for audit planning, formation of audit teams and implementation. There should be easy access to records of auditee to get audit evidence. Systems must be structured.... Time is sufficiently low to complete audit. Just 4 or 5 days to complete audit are allotted."

Another issue related to inadequacy of staff raised. Very few auditors are available to conduct audits. Moreover, staff is competent to conduct audit effectively.

Number of staff is low. Auditors have to conduct an audit from July to November. ....Three men (Senior Audit officer, Audit officer, Assistant audit Officer) or one man has to handle the audit. Due to lack of staff, mostly one auditor has to audit whole entity.... AAO and AOs are competent in terms of knowledge and Senior AOs are fifteen to twenty years experienced.

\subsection{Training of Auditors}

Training is an important factor to upgrade skills of auditors. New audit techniques need to be learnt to make audit effective. Training institutes are developed to train auditors, but they are not up to the mark. One of auditors said that,

"Effectiveness of these institutions is not up to the mark. Trainers of institutions either qualitatively or quantitatively are inefficient. Lack of Qualified trainers hampers purpose of these institutes. Short courses for training of trainees were introduced, but they are still not up to mark. Intensive training is required. Applicability of skills learned through training institutes is low e.g. skills learned are connected with IT whereas training institutes failed to connect $L A N$ and $W A N$ with the office of SAI to make access of auditors easy to database of auditee. So, training institutes lack in the accomplishment of its objectives. Training on NAM (New Accounting models) and FAM (Financial accounting model) is not conducted for auditors for the previous three years."

\subsection{Auditing Technique:}

Different audit techniques are being used worldwide, e.g., SBA (System based approach), ACL (Audit command language), sensitivity analysis, use of the voucher based system, Excel and other editing softwares, but auditors have no knowledge of these techniques. Training institutes train auditors for these applications but lack of technology create a hindrance to utilization of software. Auditors still use manual auditing systems. One of the auditors said that,

"Auditors are unaware of the SBA. This is not used as other techniques are being used. Traditionally vouchers were selected on the basis of monetary value and materiality is evaluated on the basis of transaction size. Results are generated and generalized to whole auditee. Still Voucher based sampling is used.Audit command language (ACL) is introduced to analyze data of auditee. It analyzes horizontally (one class of expenditure is analyzed on different time periods) and vertically (different classes of expenditures are analyzed in one time period and extraordinary change is recorded)."

Another said that,

"CAAT and ACL are used for evidence analysis and selection, whereas audit technique varies with type of audit. Voucher based sampling is a simple audit to check disbursement of funds with expenses incurred by audition. Internal controls are judged through regulatory, audit and financial audit. Performance audit (Efficiency, Economy, effectiveness) lacks in Pakistan. Statistical analysis-trend analysis, regression, sensitivity analysis, IRR and output budgeting is used for financial audit and evidence analysis. Financial accounting model (FAM) is used which is focused on risk analysis. Both manual and computerized techniques are used for analysis and voucher based sampling."

\subsection{Massive Corruption}

Corruption is inborn characteristic of a system that can be even at personal or professional level. Effectiveness of audit is hampered when auditors misuse audit facilities for their personal benefits, e.g. personal use of a car that was provided for official use only. One of the auditors said that,

"Transport can be misused, but staff rules regulate behavior of auditors through maintenance of a Transport register in which miles of vehicles are recorded, but still misuse of facilities exists."

Another issue is related to lack of top management support and undue pressures to change audit reports. One of the auditors said that,

"There is the massive overriding effect of top management to pressurize auditors to change audit paras which hamper the integrity of Audit Inspection Reports.... Auditors get under pressures from top management and ministries to whom their expenses are shifted and compromise on integrity of report."

Another auditor said,

"Impairment of objectivity, mental freedom and restricted resources, overriding effect of top management who gets pressurize from auditee, although government auditors have statutory shelter, lack of Culture of acceptance, abuse of power and low management support in front of auditee, all these factors hamper accountability."

\subsection{Power and Independence}

Government auditors should have full independence to operate without undue pressures. In this way they can bring accountability and transparency in the public sector. Auditors have full operational independence, but they lack 
financial independence because budget is allotted by Parliament. One of the auditors said that,

"We work independently of ministry and enjoy operational independence.... We have Operational independence, whereas financial independence rests with Parliament."

Moreover, Auditors have no powers to take actions against malpractices, they just have to report audit findings to management. They have to put forward their recommendations to rectify auditee organization. As one of the auditors said,

"We cannot execute actions against malpractices, we have recommendatory power, whereas the National Accountability Bureau (NAB) has powers to execute actions against malpractices."

\subsection{Behavior of Auditee:}

Cooperation of auditee organization with auditor can make completion of audit easy and effective, but here two important issues raised. Firstly auditee does not cooperate to produce records in a timely manner which affects the completion of the audit reports in a negative way. As one of the auditors said,

“Auditee doesn't cooperate and never willing to be audited. Limited access to records and intentional delays in production of records by auditee cause audit to be ineffective."

Second issue is denial of audit findings. Auditee does not accept audit findings. They pressurize auditors to change audit reports. If evidences against auditee are strong, auditee has to accept them. As one of the auditors said,

"If audit evidence is strong, they have to accept audit findings. If auditee justifies paras, paras are excluded, but denial always exists....... Audit paras are not changed until auditee justifies them otherwise they have to accept if strong evidences exit."

\subsection{Demotivation:}

Demotivation is another factor that makes an audit ineffective. Management does not focus on promotions of auditors in a timely manner which hampers audit effectiveness. As one of the auditors said,

"Willingness to work is low and staff is demotivated because promotional aspects are ignored by SAI. Further progression is zero and brains of the department are in difficulty."

\subsection{Audit Criteria:}

Different interviewers presented different definitions of audit criteria,

"Audit criteria are standards or rules imposed by government. For example, government bans purchase of car of specific companies. It is criteria to evaluate transactions about vehicles.... Audit criteria are the rules and regulations either of auditors or audit. Auditors check compliance of auditee with rules developed by auditee and government either they are following those rules and auditors report to management about loopholes."

"Audit criteria are defined by government rules-General financial rules(GFR),FRSR(Fundamental rules and support rules, Federal treasury rules, Orders, SRO(Statutory, Regulatory audit).Audit criteria varies with type of audit(Regulatory, compliance, performance or financial audit)."

Continuous variation in auditing criteria can make audit ineffective. Auditors will be unable to set performance standards and compare performance of auditee with previous performance levels. One auditor said,

"Auditing standards and basic rules of government auditing remain same but audit criteria vary with the auditee to audit because audit is conducted to check either auditee is following rules. Auditors do not have its own rules, but audit methodology remains same."

\subsection{Auditor's Follow up}

Auditors have to follow up auditee to observe either auditee has adopted recommendations made in previous audit or not. Government auditors have proper channel and a system to follow up audit. As one of the auditors said,

"Auditors follow up auditee. Next auditor has to confirm the extent to which previous recommendations were followed. Restricted time is available for follow up and thirty days are given to auditee to respond but auditee does not respond. Letters are sent to them. When audit reports are prepared, the interdepartmental committee of auditors' discusses reports with audited, if audit reports are settled, then those reports is excluded otherwise they are forwarded to government."

\section{Conclusions and Discussion}

The first research objective is to discover the factors which affect working of auditors to conduct audit effectively and the second objective is to compare findings with the findings of western and Asian research work. It can be concluded that government auditors in Pakistan are suffering from the same problems which are being faced by government auditors in UK[13], US[14], West Australia[15], Estonia[18], Israel[20], Bangladesh [21], Indonesia[23], Turkey [24], Ghana [25], Europe[29,30] and Ethiopia [31]. Government auditors in Pakistan are suffering from several restraining factors which include lack of technology, financial resources and human resources $[11,12,13,17,19]$, restricted access to records of auditee, limited time available for audit, lack of staff competency[13,14], ineffective 
training institutes and qualified trainers[9,10],weak applicability of new auditing methods[15], high need of learning materials ,auditee size[31], massive corruption[13,16], resistance to new computerized auditing techniques[15], lack of powers to take actions against malpractices and deviations[24], full operational independence and lack of financial independence $[23,30]$,political pressures and lack of top management support $[13,14,17,20]$,lack of auditee cooperation to accept audit findings $[13,14,16,21,31]$, heavy reliance on auditee for audit, lack of promotions[20,29],follow up of auditee[26] ans massive corruption are affecting government auditors of Pakistan to conduct effective audits. Government auditors are unable to bring accountability and transparency in an effective manner because of several restraining forces. They are unable to present a true picture of government entities which directly affects budgeting decisions of Parliament. Government entities use public money for personal benefits rather than the public welfare. In nutshells, it can be concluded that when audits are unable to deliver true facts, the public loses trust in government, moreover, the economic welfare of the country remains at stake.

\section{Recommendations}

The third research objective is to suggest remedial measures to improve audit effectiveness. Several recommendations are suggested by the researcher and the auditors. Audit effectiveness can be increased through paying attention to restraining forces.

- Performance appraisals of staff should be conducted in a timely manner to have a check and balance on employees and must recommend performance indicators for auditors. Government should provide career opportunities to enhance motivation and satisfaction level with the job.

- System of merit based recruitment rather than favoritism based recruitment should be introduced. Highly educated and technologically aware professionals should be selected.

- Auditors should be timely promoted on a performance basis rather than seniority.

- Training sessions should be conducted to upgrade audit skills.

- Audit teams should comprise both new and experienced auditors to share experiences, explicit and implicit. In this way, training cost can be saved through on the job training methods. Employees can learn and share in good manner.

- Government auditors face different problems due to lack of financial resources. They heavily rely on auditee for stationaries, food, conveyance, photocopiers and other needs which creates a negative perception about government auditors. Appropriate budget should be assigned to eliminate that reliance.

- Appropriate number of employees should be hired to equally share burden of work.

- Top management must support auditors to conduct audit honestly and fairly. Audit paragraphs must not be changed on directions of political pressures and personal interest of management.

- Technology should be upgraded in a timely manner to encourage all employees to use computerized auditing techniques.

- Audit findings should be shared with public. Communication strategy should be adopted to communicate audit findings in easily understandable wording in general public. In addition to it, media whistle blowing activities and civil participation in audits should be encouraged.

- Auditors must follow auditee to check either they are following recommendations. This follow up will reduce chances of further errors and mistakes.

- Auditors should have powers to take actions against frauds in financial data rather than merely reporting.

\section{Implications}

This research work opens a different theoretical and methodological dimensions and potential for further research on government audits and auditors as well. Being an exploratory research, it serves as a base to separately test each variable with effectiveness of government audits. Researchers can use these variables in different ways. The regression and correlation techniques can be applied which were avoided in this research because purpose of study was exploratory rather than relationship testing.

\section{Annexure A}

\section{Interview Guide}

1. Are Training Institutes helpful to train auditors?

2. Do you think training provided by these institutions sufficient enough to prepare auditors play their role effectively?

3. Apart from training, in your opinion can be other programs or sessions which will be helpful for auditors?

4. System based audit -a new approach of audit was used to conduct audit in ministries under Medium Term Budgetary Framework. What do you know about this type of technique?

5. Which auditing technique do you use for evidence selection and analysis? Is it useful?

6. What kind of new approach your department introduced for evidence selection and analysis?

7. Which kind of audit facilities does audit team need to conduct audit effectively?

8. Is audit team honest enough to treat these facilities only for audit purpose?

9. Is adequate number of staff available to conduct 
audit?

10. Is staff competent enough to conduct audit effectively?

11. Does auditee/formation accept whatever loopholes about budget utilization are identified in audit reports?

12. Is your staff engaged in manipulating audit audits repeatedly?

13. Are you provided with sufficient time in proportion to size of auditee/formation to conduct audit effectively?

14. Do you follow up auditee/formation either they are implementing audit recommendations or not?

15. Which audit criteria and audit standard are you following?

16. Do audit criteria vary from auditee to auditee?

17. What kinds of problems are being faced by auditors?

18. Does your top management support the integrity of the report or get pressurized to change facts?

19. Do you enjoy independence from ministries to deliver transparent audit reports?

20. Does parliament allocate sufficient budget to meet auditors' needs?

\section{REFERENCES}

[1] Geogopulus.B,Tannnebum.A.(1957),Study of Effectiveness, American Sociological, Vol 22,pp 534-540

[2] Campbell, J. (1990). Modeling the performance prediction problem in industrial and the impact of HR practices on the performance of business units, organizational psychology, Handbook of Industrial and Organizational Psychology (2).

[3] Budhwar, S.P. \& A.A. Katou, (2010), causal relationship between HRM policies and organizational performance: Evidence from the Greek manufacturing sector, European Management Journal 28, 25-39.

[4] Teseema, M. \& J. Soeters, (2006). Challenges and prospects of HRM in developing countries: testing the HRM-performance link in Eritrean civil service, International Journal of Human Resource Management, 17(1), 86-105.

[5] Singh, K. (2004). 'Impact of HR practices on perceived firm performance in India'. Asia pacific Journal of Human Resources 42(3) 301-317.

[6] Huselid, M.A., \& B. Becker.(1995). High performance work systems and organizational performance, Paper presented at the annual meeting of the Academy of Management, Vancouver.

[7] Ahmad.S, Schroeder.R.G.(2003), The impact of human resource management practices on operational performance: recognizing country and industry differences, Journal of Operations Management ,vol $21,19-43$

[8] Cartin, Thomas J. (2004). Principles and Practices of Organizational Performance Excellence, paper presented in New Delhi: Prentice Hall

[9] Al Emadi, M.A.S and Marquardt M.J.(2007), relationship between employees beliefs regarding training benefits and employees organizational commitment in a petroleum company in the state of Qatar ,International Journal Of Training And Development, vol 11,1,49-69

[10] Ghafoor.R, Furqan.F \& Aslam.M.(2011),Impact of Training and Development on Organizational Performance, Global Journal of Management and Business Research, Volume 11 ,Issue 7

[11] Rainey, Hal G., and Paula Steinbauer. 1999. Galloping elephants: Developing elements of a theory of effective government organizations. Journal of Public Administration Research and Theory, 9 (1): 1-32.

[12] Irwin.J.G, Hoffman.J.J b,Lamont.B.T.(1998), The effect of the acquisition of technological innovations on organizational performance: A resource-based view,Journal of Engineering and technology management,25-54( 15)

[13] Hedger, E. Blick, A.(2008), Enhancing accountability for use of public sector resources, how to improve effectiveness of public accounts committee, retrieved from http://www.odi.org.uk/p ublications/2598-enhancing-accountability-use-public-sector -resources-improve-effectiveness-public - accounts-committ ee

[14] Choi, J. H., Kim, C., Kim, J. B., \& Zang, Y. (2010). Audit office size, audit quality, and audit pricing. Auditing: A Journal of Practice \& Theory, 29(1), 73-97.

[15] Chong, K. M., Dolley, C., Houghton, K. A., \& Monroe, G. (2000). Resource Allocation and Efficiency in Public Sector Audits. Edith Cowan University.

[16] Coghill, K. (2004, February). Auditing the independence of the Auditor-General. In Seminar paper presented on (Vol. 11).

[17] Weir, C., Laing, D., \& McKnight, P. J. (2002). Internal and external governance mechanisms: their impact on the performance of large UK public -companies.Journal of Business Finance \& Accounting, $29(5$ 6), 579-611.

[18] Etverk, J.(2002),Measuring performance audit effectiveness-case of Estonia, University of Tartu, retrieved from www.riigikontroll.ee/linklick.aspx?fileticket=N9rrJVSUJH M\%3Dtabid=124dmid=735\&language=et-EE\&forcedownlo $\mathrm{ad}=$ true

[19] Mills, C., \& Swarbrick, G. Going with the grain: organising for a purpose.

[20] Cohen, A. Sayag,G. (2010), Effectiveness of internal auditing, an empirical examination of its determinants in Israeli Organization, Australian Accounting Review,20(3),296-307

[21] Hussain, Z. (2011). Effectiveness of the Office of the Comptroller and Auditor General of Bangladesh in Ensuring Accountability of Auditee Organizations: A Case Study of an MTBF Ministry.

[22] Chowdhury, R.Innes,J. Kouhy,R. (2005),Public sector audit expectations in Bangladesh, Managerial Auditing Journal,20(8),893-908

[23] Dwiputrianti, s.(2011), Role of Indonesian GOVERNMENT AUDIT INSTITUTION in financial transparency and performance accountability, Paper presented at ASIASIA,ASPA and Xiamen University retrieved from 
http://www.academia.edu.com

[24] Kayrak, M. (2008), Evolving challenges for supreme audit institutions in struggling with corruption, Journal of financial crime, 15(1),60-70

[25] Van Thiel, S., \& Leeuw, F. L. (2002). The performance paradox in the public sector. Public Performance \& Management Review, 267-281.

[26] Khumalo,M.(2007),Investigation of efficiency of office of Auditor General in ensuring public financial accountability in Gauteng province, retrieved from

http://uth.retd.ac.za/bitstream/10353/283/1/whole\%20MPA

$\% 20$ research-3.pdf

[27] Montero.A.(2012), Building bridges:Advancing transparency and participation through the articulation of Supreme Audit Institutions and civil society, Paper presented at the 2nd Transatlantic Conference on Transparency Research
[28] Pacific Association Supreme Audit Institution.(2012),Improving governance of public sector operations in Pacific region, retrieved from http://www.paGovernment Audit Institution.org/site/paGove rnment

AuditInstitution/files/press_release?2012//accountability_an d\%20-transparency_report_final_2011.pdf

[29] Tudor,A.(2007),Performance audit in public sector entities-a new challenge for Eastern European countries, Transy Lvavian review of administrative sciences, 19,126-141

[30] Sacer.I ,Zager.L,Sever .I.(2011),An accountability of supreme audit institutions in the European union countries, Proceedings of the International Scientific Conference, Juraj Do, p81

[31] Yismaw.A, Miheret.J. (2007), Internal audit effectiveness: an Ethiopian public sector case study, Managerial Auditing Journal 22 (5), 470-484 